\title{
Past and present distribution of the cryptic species Leptidea sinapis and $L$. reali (Lepidoptera: Pieridae) in Poland and its implications for the conservation of these butterflies
}

\author{
Konrad SACHANOWICZ1 ${ }^{1}$, AgnieszKa WOWER ${ }^{2}$ and JarosŁaw BUSZKO ${ }^{3}$ \\ ${ }^{1}$ Museum and Institute of Zoology, ul. Wilcza 64, 00-679 Warszawa, Poland; e-mail: chassan@poczta.onet.pl \\ ${ }^{2}$ Upper Silesian Nature Heritage Centre, ul. św. Huberta 35, 40-543 Katowice, Poland; e-mail: a.wower@cdpgs.katowice.pl \\ ${ }^{3}$ Department of Animal Ecology, Nicolaus Copernicus University, ul. Gagarina 9, 87-100 Toruń, Poland; e-mail: buszko@umk.pl
}

Key words. Leptidea, distribution, range changes, expansion, habitat preferences, conservation status, central Europe

\begin{abstract}
Using a large sample of museum and newly collected specimens of the cryptic butterfly species Leptidea sinapis and L. reali, identified/confirmed based on genital characters, the patterns in their geographical distributions, historical changes in range and briefly also their habitat associations in Poland, were investigated. Leptidea sinapis occurs mainly in the lowland and upland parts of the country and is rarer than L. reali, which is widespread throughout Poland, including the mountains. In the first half of the $20^{\text {th }}$ century, the range of $L$. sinapis included the whole of Poland, whereas currently it is confined to eastern and southern regions. Historical records of the distribution of $L$. reali are concentrated in southern and central Poland. Currently it is recorded from localities throughout Poland. Leptidea reali is recorded most frequently in meadows and shows no clear preference for a particular level of humidity, while L. sinapis is found mainly in woodland and xerothermic habitats. The two species are syntopic within the present range of $L$. sinapis, which is now a declining and local species, whereas $L$. reali is now common and widespread.
\end{abstract}

\section{INTRODUCTION}

It was only in 1988 that P.G.J. Réal demonstrated that Leptidea sinapis consists of a pair of cryptic species: $L$. sinapis sensu stricto (Linnaeus, 1758) and $L$. reali Reissinger, 1989 (originally but erroneously named $L$. lorkovicii Réal, 1988), newly-described from the eastern Pyrenees (La Montaillé, 1300 m, SW France) (see Lorković, 1993). That discovery was one of the greatest curiosities in European entomology in recent decades. It was also surprising since the biology of L. sinapis sensu lato was relatively well studied (e.g. Warren, 1984, 1985; Warren et al., 1986). The morphological and ecological distinctiveness of both taxa was confirmed by later research, in which the qualitative and quantitative diagnostic features of their genitalia were described (Lorković, 1993). The specific status of these sibling species has also been confirmed by genetic methods (Martin et al., 2003). The two species apparently do not cross and produce inter-specific hybrids (Martin et al., 2003; Friberg et al., 2008a), although the possibility of occasional hybridisation, between female $L$. sinapis and male $L$. reali, cannot be excluded (Verovnik \& Glogovčan, 2007). Behavioural reproductive isolation is recorded both in captivity and in nature for this pair of extremely similar species, functioning by means of female choice and resulting in only conspecific matings (Lorković, 1993; Freese \& Fiedler, 2002; Friberg et al., 2008b). Data published hitherto relate to the general and local distribution of both species in Europe (e.g. Beneš et al., 2003; Mazel \& Eitschberger, 2003; Vila et al., 2003), their morphological variability (Lorković, 1993; Freese \& Fiedler,
2004; Friberg et al., 2008b; Schmitz, 2007), local habitat preferences (e.g. Warren \& Bourn, 1998; Beneš et al., 2003; Amiet, 2004; Verovnik \& Glogovčan, 2007; Friberg et al., 2008a, c), reproductive behaviour and selected aspects of larval ecology (Fiedler \& Freese, 2002; Friberg et al., 2008a, b; Friberg \& Wiklund, 2008). Historical distributional data are available for Switzerland (Rezbanyai-Reser, 2005), Holland (Cupedo \& Hoen, 2006) and north-western Germany (Schmitz, 2007).

Although both species are still treated as the " $L$. sinapis complex" in "The Distribution Atlas of European Butterflies" (Kudrna, 2002), it is clear that they are widespread and occur sympatrically throughout the continent, from the Iberian Peninsula to the Urals and northwards to Ireland, Scandinavia and northern Russia. L. reali appears to be absent from the western part of the Iberian Peninsula, England and the Mediterranean islands (Lorković, 1993; Embacher, 1996; Mazel \& Leestmans, 1996, 1999; Nelson et al., 2001; Mazel \& Eitschberger, 2002, 2003; Rezbanyai-Reser, 2005). Distributional data for Poland relate only to L. sinapis s. 1. Buszko (1997) states it occurs throughout the country, usually common and rare only in the north-west. Lorković (1993) gives the first recorded Polish locality of $L$. reali (Ostrów, near Ropczyce, 15.vii.1930, leg. S. Stach). Skalski (1995) reported that this species is widely distributed in southern Poland and likely to be common in the whole country. Scarce published records of $L$. reali (without localities) are included in the country's distributional checklist (Buszko \& Nowacki, 2000).

This study aims to (1) discover the historical and establish the present distribution of both Leptidea species in 


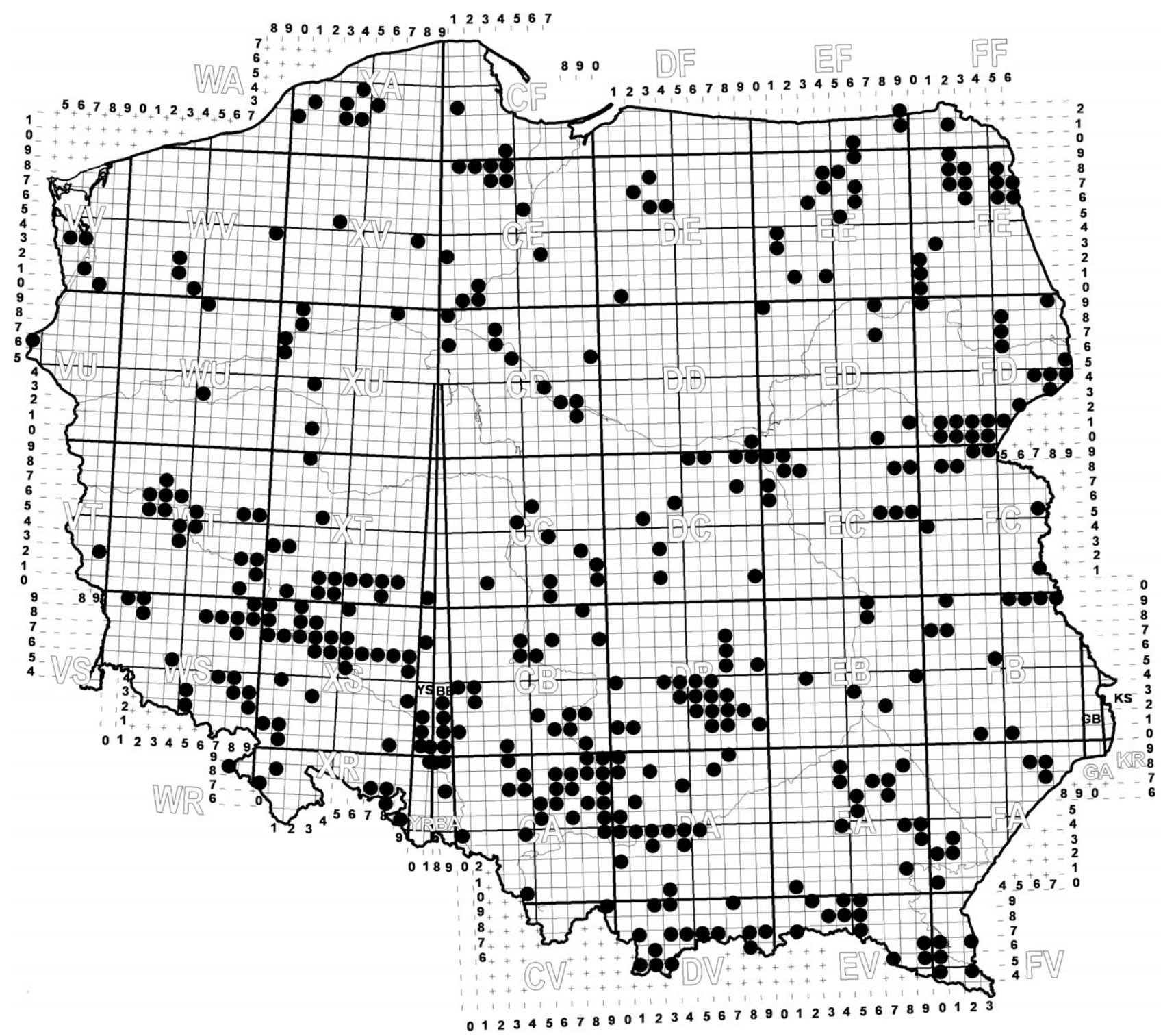

Fig. 1. Distribution of the localities of two species of Leptidea in Poland in the years 1892-2007.

Poland and to define their conservation status, (2) examine the direction and scale of historical changes in the geographical ranges of both species and (3) determine whether Skalski's (1995) hypothesis that L. reali is widespread in Poland is correct. To a minor extent this study also contributes to our knowledge of the habitat associations of the two species in Poland, which are particularly important for understanding their conservation requirements and hence for facilitating predictions of the effect of environmental changes on the distribution of these butterflies.

\section{MATERIAL AND METHODS}

Leptidea specimens were identified based on their genital characters (the length of the antrum bursae in females and the length and shape of the aedeagus and saccus in males) (Lorković, 1993; Segerer, 2001; Freese \& Fiedler, 2004; RezbanyaiReser, 2005; Schmitz, 2007). The morphological variation in genital characters in Polish Leptidea will be described elsewhere. Differences in the adult wing pattern (e.g. the shape of the dark apical spot in males) have proved to be too weak and subjective to be of any practical use (Freese \& Fiedler, 2004; Rezbanyai-Reser, 2005; Friberg et al., 2008b).

The database contains 1345 records of Leptidea including personally examined and identified/confirmed specimens from museums and private collections (see Acknowledgements) and several published records (Blaik, 2006). The oldest available records of the two species from Poland (L. sinapis $q$ and $L$. reali $q$ Siedlce, UTM EC 88, vii.1892 and 29.vi.1892, leg. O. Brehm) are based on records in the Orion Entomologische Gesellschaft - Berlin: www. orion-berlin.de/projekte/schmetter/ tag/sin_tab_2). Only specimens with a precise record of the locality where captured and date were used in this analysis, except for three, where the period of collection was established on the basis of additional information. Specimens collected recently (2004-2007) in different parts of the country by the authors and their co-workers are also included in this study (see Acknowledgements). If present, several individuals were usually collected in different habitats, at each site, increasing the probability of detecting both species.

The geographical distribution of Leptidea is shown on maps constructed using the UTM $10 \mathrm{~km}$ grid system (3318 "squares" in Poland) and Gnomon 3.0 software (Desmodus, Jarocin). 


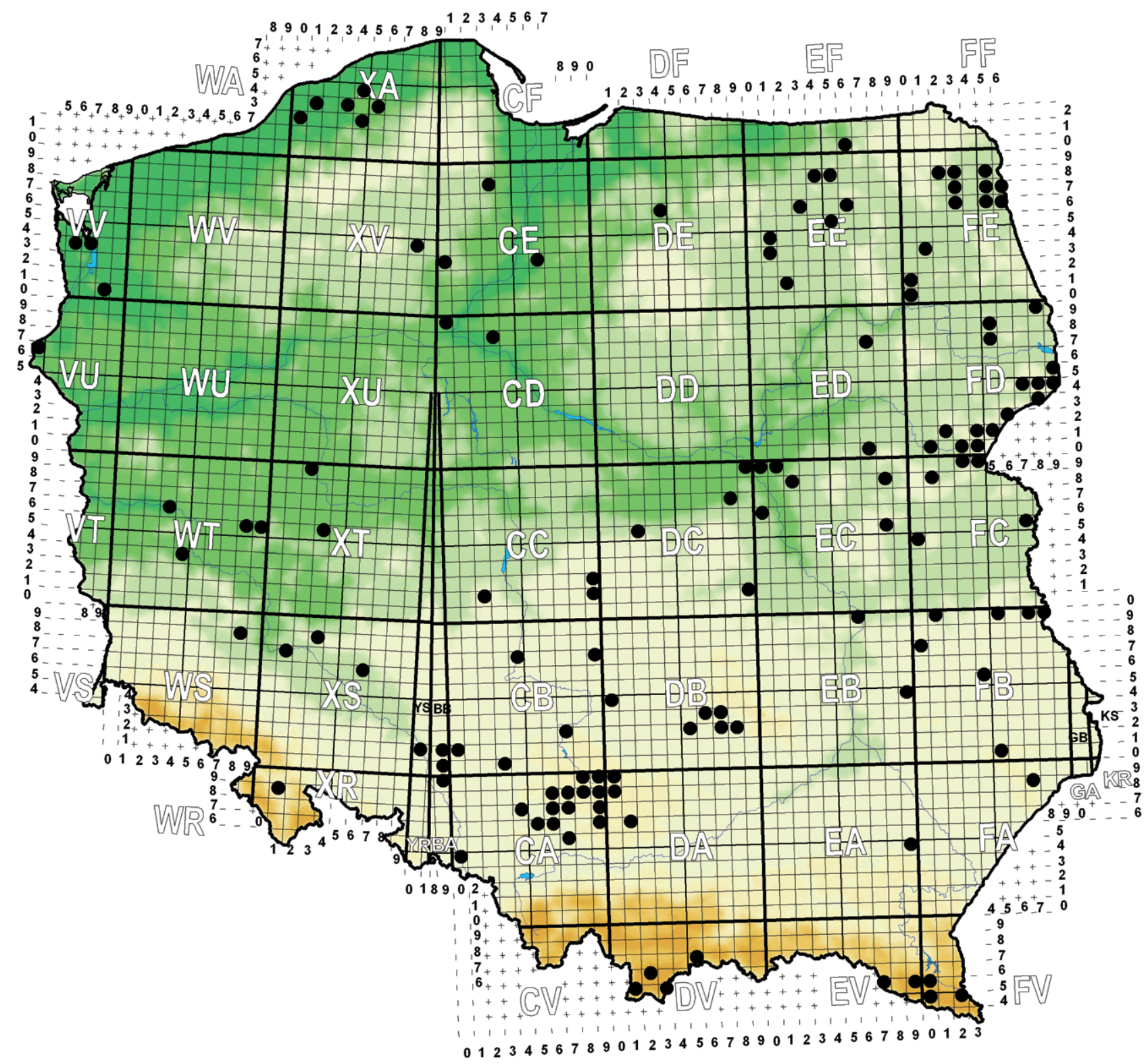

Fig. 2. Distribution of the localities of L. sinapis in Poland in the years 1892-2007.

Records were divided into two periods: historical (a - from 1892 to 1945 and $b-1945$ to 1985 ) and present (from 1986 to 2007). The onset of the last period coincides with the beginning of the "Distribution Atlas of Polish Butterflies" project (Buszko, 1997).

Data permitting a general description of the habitat affiliations of these butterflies were collected in the field by the authors and some co-workers, mainly in 1986-2007. Some older data linked to museum specimens were also used. The habitats at the butterfly capture sites were categorised according to their type (forest and meadow habitats) and humidity (X - xerothermic, ME - mesophilous and $\mathrm{H}$ - hygrophilous; Verovnik \& Glogovčan, 2007). Woodland habitats (semi-open) include shade-providing habitats within woodland and along its edges, like clearings and roadsides. Meadow habitats refer mainly to open grasslands and low scrub away from or adjoining woodland. Data were available for 253 (L. sinapis -60 , L. reali 193) and for 197 (L. sinapis -46, L. reali - 151) localities in woodland and meadow habitats, respectively. It can be assumed that both species were obtained in proportion to their occurrence

TABLE. 1. Number of localities of Leptidea recorded in Poland in the years 1892-2007 and three sub-periods: 1892-1945, 1946-1985 and 1986-2007. N - number of localities, UTM - number of $10 \mathrm{~km} \mathrm{UTM} \mathrm{"squares".}$

\begin{tabular}{|c|c|c|c|c|c|c|c|c|}
\hline \multirow{2}{*}{ Species } & \multicolumn{2}{|c|}{ 1892-1945 } & \multicolumn{2}{|c|}{ 1946-1985 } & \multicolumn{2}{|c|}{ 1986-2007 } & \multicolumn{2}{|c|}{$1892-2007$} \\
\hline & $\mathrm{N}$ & UTM & $\mathrm{N}$ & UTM & $\mathrm{N}$ & UTM & $\mathrm{N}$ & UTM \\
\hline L. sinapis & 50 & 43 & 69 & 48 & 69 & 59 & 181 & 137 \\
\hline L. reali & 59 & 47 & 96 & 72 & 310 & 246 & 454 & 333 \\
\hline$\Sigma$ & 109 & 90 & 165 & 120 & 379 & 305 & 635 & 470 \\
\hline
\end{tabular}




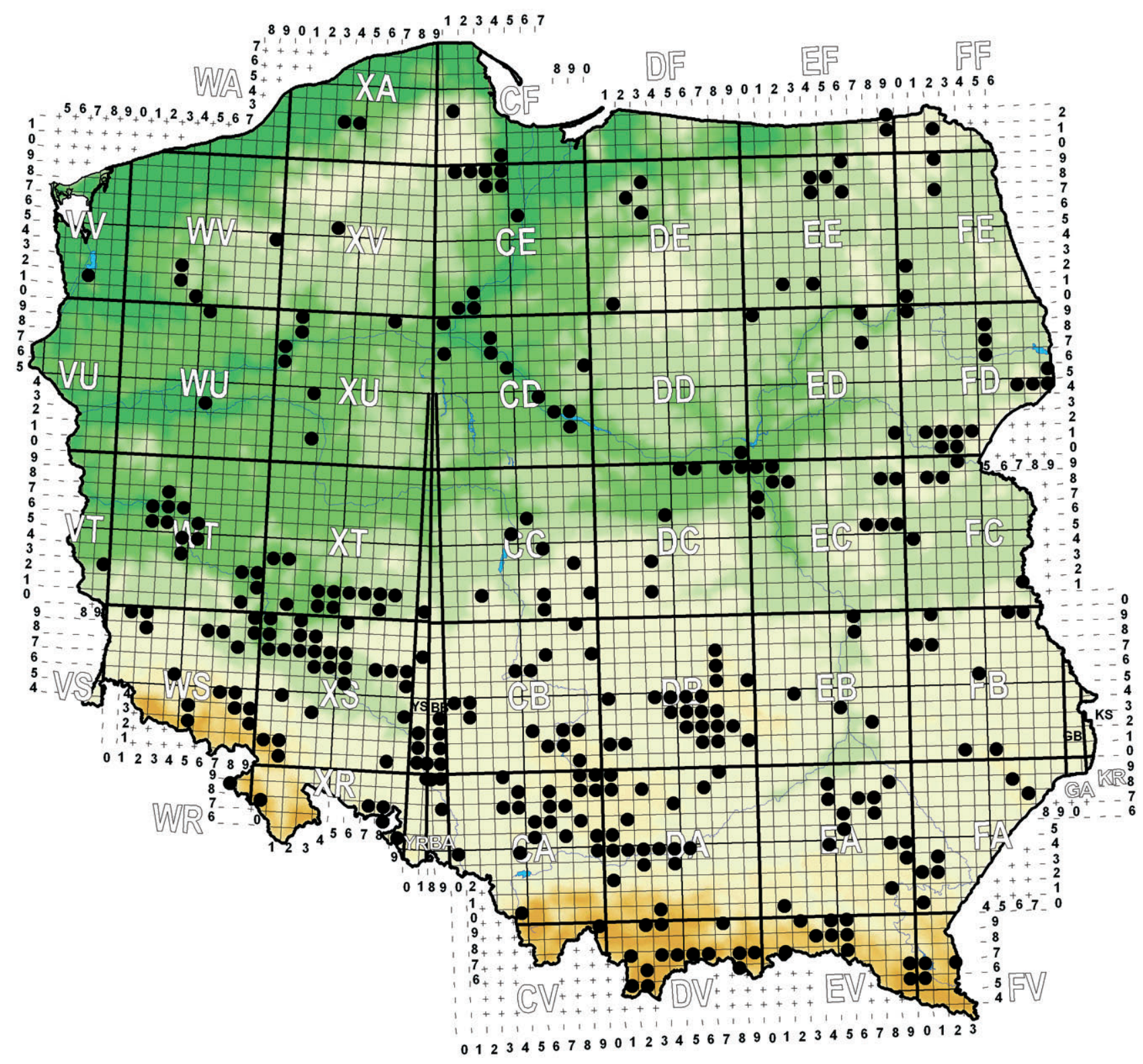

Fig. 3. Distribution of the localities of L. reali in Poland in the years 1892-2007.

in the different habitats; since they are indistinguishable in the field it is unlikely that they were captured selectively.

\section{RESULTS}

\section{Distribution}

Both Leptidea species $(\mathrm{n}=635$, in 470 UTM grids) occur throughout Poland (Fig. 1), with L. sinapis (181 sites) significantly rarer than $L$. reali $(454)$ both in the past $\left(\chi^{2}=4.73\right.$, df $\left.=1, p<0.034\right)$ and currently $\left(\chi^{2}=\right.$ $153.25, \mathrm{df}=1, \mathrm{p}<0.0001$ ) (Table 1). In the case of $L$. reali the number of localities has gradually increased in subsequent periods. L. sinapis is less evenly distributed, being concentrated mainly in the lowland and upland parts of the country. There are only a few sites for this species in the mountains: two areas in the Carpathians and just one in the Sudetens (Figs 2-3). In both of these mountain ranges $L$. reali is more widespread than $L$. sinapis. There is a surprising lack of $L$. sinapis records along the River Wisła (Vistula) in the Kraków area, that has been well sampled. Only this species is recorded in the interior of the extensive Augustów forest (8 UTM grids, Fig. 2) in the north-eastern corner of Poland.

\section{Range changes}

The geographical ranges of the two species changed markedly during the $20^{\text {th }}$ century and displayed opposite trends. In the past, localities of $L$. sinapis were distributed more or less evenly in all parts of the country (Fig. 4). In recent decades, however, it has not been recorded in most of western and central Poland, suggesting a marked reduction and probably also fragmentation of its range, with most of the recent records for north-eastern Poland (Fig. 5). The oldest records for $L$. reali are for southern and central Poland. Before 1985 it was present in northeastern and western regions (Fig. 6). In recent decades this species has been recorded at localities throughout the 


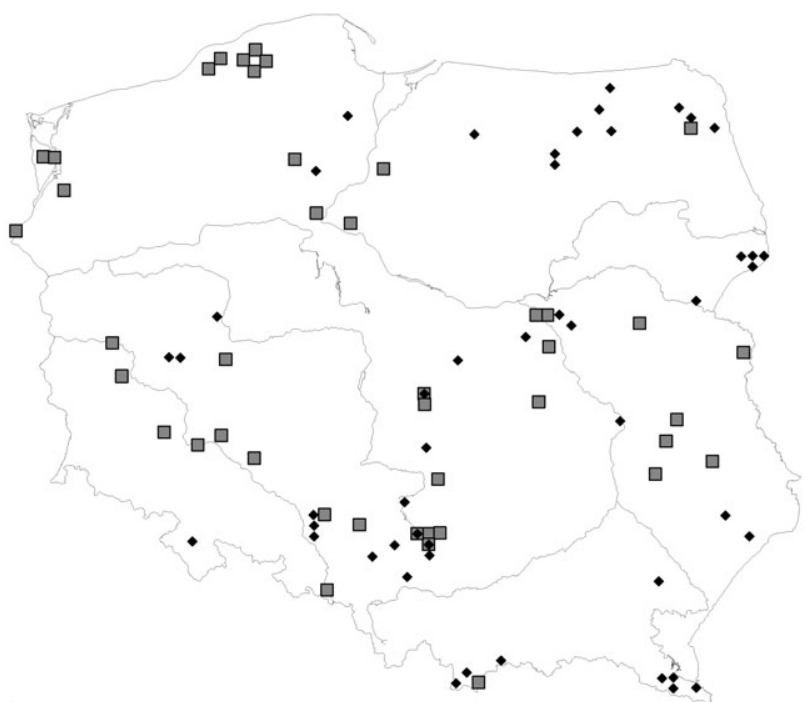

Fig. 4. Distribution of historical records of the localities of $L$. sinapis in Poland: 1892-1945 grey squares, 1946-1985 black diamonds.

whole country, including the north-west (Fig. 7), where only $L$. sinapis used to be present. This, in combination with increasing numbers of localities in later periods, is indicative of the continuous expansion and successful recent colonisation of the whole country.

\section{Habitat affiliations and species co-occurrence}

Although both species are recorded in meadows and woodland they exhibit a significant association with habitat $\left(\chi^{2}=24.96\right.$, df $\left.=1, \mathrm{p}<0.0001\right)$, with $L$. reali more frequently recorded in meadows $(64 \%, \mathrm{M}=124, \mathrm{~F}$ $=69)$ and $L$. sinapis in woodlands $(73 \%, \mathrm{M}=16, \mathrm{~F}=44)$. The two species also differ in frequency of occurrence with respect to habitat humidity $\left(\chi^{2}=8.25, \mathrm{df}=2, \mathrm{p}<\right.$ 0.02): L. sinapis preferred xerothermic habitats $(56 \%, \mathrm{X}$ $=26, \mathrm{ME}=10, \mathrm{H}=10$ ), but was also present in other habitats, whereas $L$. reali displayed no clear preference $(\mathrm{X}=50, \mathrm{ME}=46, \mathrm{H}=55)$. Both species co-occurred within the current L. sinapis range; in the period 1986-2007 they were found to coexist at 29 localities, including 20 with confirmed syntopy (Fig. 8). These sites were distributed in all parts of the sympatric range except the mountains, in both types of habitat and independent of humidity.

\section{DISCUSSION}

There is a noticeable compatibility between the historical and present distributions of both species and the detection of continuous trends in their range changes. This study provides an explanation of the earlier detected difference in the occurrence of Leptidea sinapis s. 1. in north-western Poland and the rest of the country. The distribution of this species published in the distribution atlas (Buszko, 1997) corresponds to the present occurrence of $L$. reali and hides the real distribution of $L$. sinapis. The results presented here confirm Skalski's (1995) hypothesis of the ubiquity of $L$. reali in Poland, which ranks it among the common Polish butterflies. Although

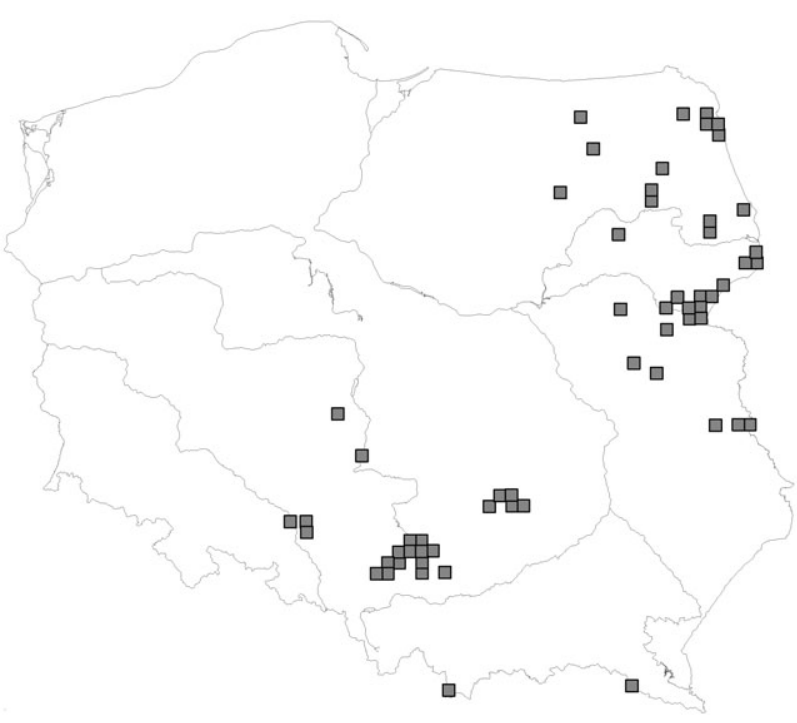

Fig. 5. Distribution of the localities of L. sinapis in Poland in the years 1986-2007.

there may be some gaps in the present range of L. sinapis, which possibly is larger than actually detected, the species should be considered as local and declining in Poland instead as common and widespread. The distributions of the two species differ also in the Czech Republic, where L. sinapis is more common only in southern Moravia, whereas in the north and in the western Sudetens it is very local or absent altogether. As in Poland, L. reali is widespread and common throughout the country, including the cooler mountain areas (Beneš et al., 2003).

Although both species are usually sympatric their proportions vary with latitude, most likely because of differences in habitat and thermal preferences. In central Europe and Ireland $L$. reali is more widespread and common (Beneš et al., 2003; Hughes \& Nelson, 2004; Schmitz, 2007; Verovnik \& Glogovčan, 2007; this paper).

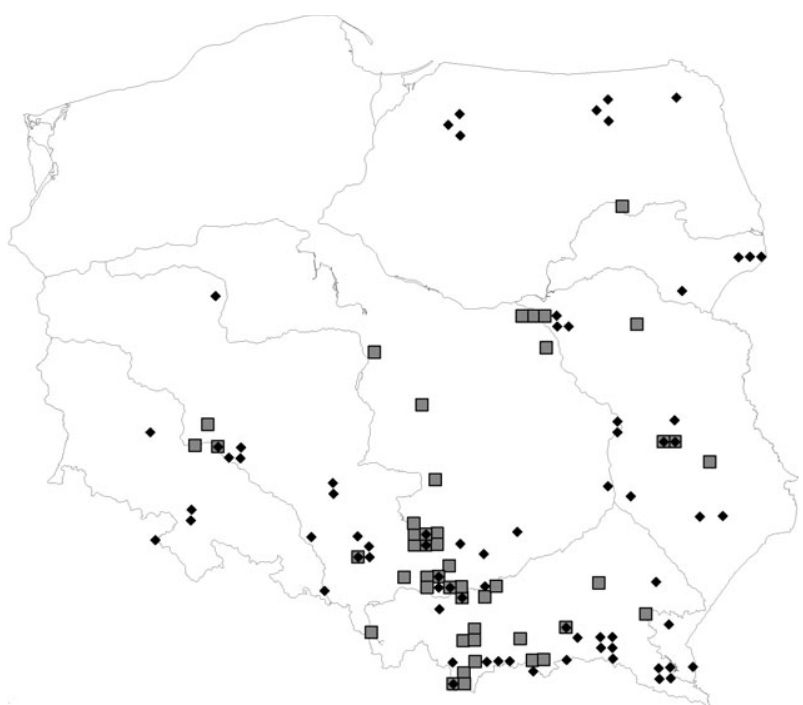

Fig. 6. Distribution of historical records of the localities of $L$. reali in Poland: 1892-1945 grey squares, 1946-1985 black diamonds. 


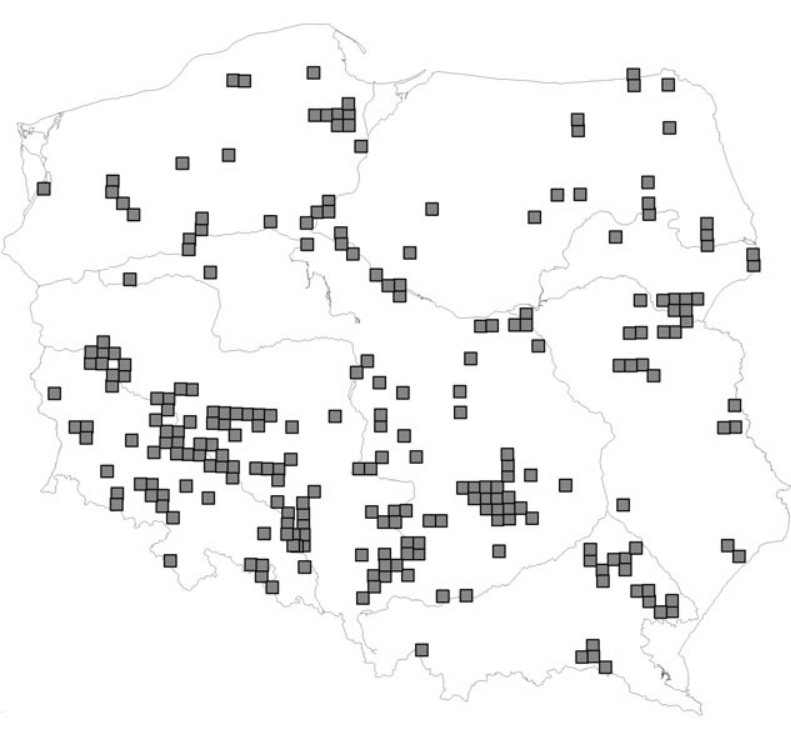

Fig. 7. Distribution of the localities of $L$. reali in Poland in the years 1986-2007.

The more thermophilous L. sinapis is dominant in Mediterranean regions and in southern Europe, including Switzerland, where L. reali is local and occurs in more humid and cooler habitats at higher altitudes (Mazel \& Eitschberger, 2003; Vila et al., 2003; Amiet, 2004; RezbanyaiReser, 2005). The climate-associated border of the dominance zone is clearly in Slovenia, where L. reali is more common throughout the country (continental climate zone), except on the Mediterranean coast (Verovnik \& Glogovčan, 2007). The situation in the Balkans is unknown. In Bosnia and Herzegovina L. reali is apparently confined to the north-eastern part (Lelo, 2007) and only L. sinapis is known from Albania (K. Sachanowicz, unpubl. data).

Recent findings indicate that the conservation status of the two Leptidea species differs, with L. sinapis being more vulnerable, at least in central Europe and Ireland. In the $20^{\text {th }}$ century the distributional range of L. sinapis in England and Wales declined by $62 \%$ (Warren \& Bourn, 1998). Recently, the two species were considered extinct in Denmark: L. sinapis since the 1960s and L. reali since 2003 (Karsholt, 1999; Schmitz, 2007). In the Netherlands, L. sinapis has always been rare and is currently restricted to the south of the country. The oldest Dutch specimens of $L$. reali are from 1901 and this species has always been rare and restricted to the southeastern part, with its presence there not confirmed since the 1950s (Cupedo \& Hoen, 2006). L. sinapis was dominant in north-western Germany at the beginning of the $20^{\text {th }}$ century, but after a gradual decrease had almost disappeared. Simultaneously, L. reali became more common and dominant in the mid- $20^{\text {th }}$ century. It has colonised new areas and increased in numbers during recent decades (Schmitz, 2007; O. Schmitz, pers. comm.). In central-eastern Germany (Brandenburg) only L. sinapis was present until the early 1970 s, when $L$. reali was recorded there for the first time. The latter species has continued to expand its range since then (Gerstberger \&

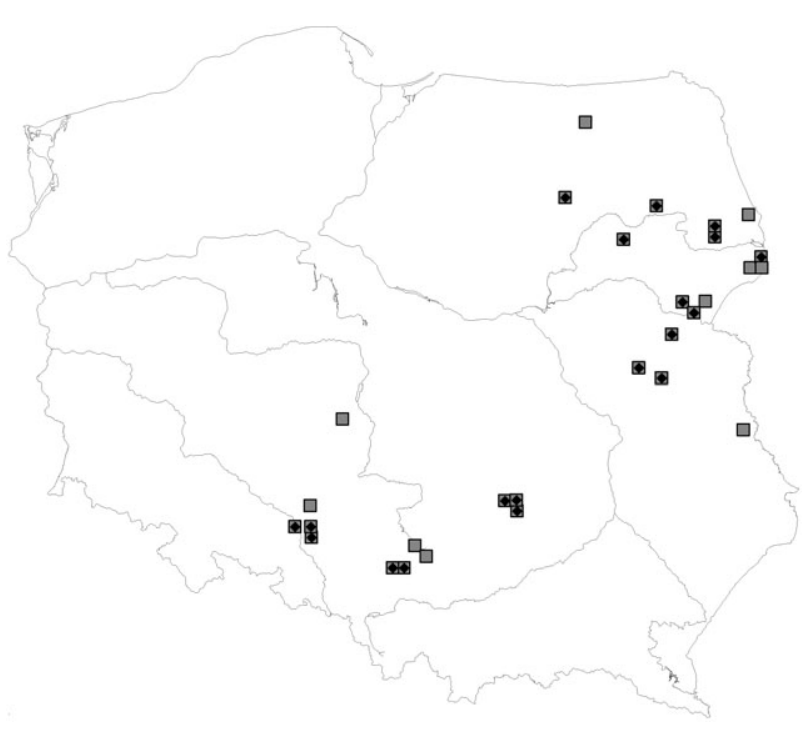

Fig 8. Distribution of the localities, where the two Leptidea species coexisted in Poland in the years 1986-2007: grey squares - sympatric occurrence, black diamonds - syntopic occurrence.

Woelky, 2004). Moreover, the date of its appearance in Brandenburg coincided with the time of its detection in north-western Poland (this paper). In Ireland, after 1945, $L$. reali increased and expanded rapidly from the south to colonise the whole island. It was thought to have spread during just a few decades using a network of suitable habitats that became available along disused railway lines, and that this process could even have been accelerated by the passive transport of larval stages on goods trains (Warren \& Bourn, 1998; Nelson et al., 2001).

The syntopic presence, common locally, of the two species across Europe (Beneš et al., 2003; Amiet, 2004; Rezbanyai-Reser, 2005; this paper) is facilitated by the broad overlap in their habitats and trophic niches. Although some differences in host plant utilisation are reported, with $L$. reali using mainly Lathyrus pratensis and L. sinapis generally preferring Lotus corniculatus and L. pratensis among several other plants (Lorković, 1993; Freese \& Fiedler, 2002; Amiet, 2004; Friberg \& Wiklund 2009), an experimental study has demonstrated a lack of potential inter-specific differences in female host plant preference (Friberg \& Wiklund, 2009).

The association of $L$. reali primarily with grasslands has been confirmed in different parts of its range (Verovnik \& Glogovčan, 2007; Friberg et al., 2008a; this paper). In Poland this species occurs in woodlands, a fact that may be related to the spatial structure and common presence of grassy glades and roadsides in this habitat. Our data confirm that $L$. sinapis is more a forest butterfly than $L$. reali, as is recorded for this species in northern Europe (Warren, 1984; Friberg et al., 2008a). The apparent relationship with shade-providing habitats like woods, their edge zones and scrub - sites preferred by butterflies provide 20-50\% shading (Warren, 1985; Warren et al., 1986) - may be related to differences in flight performance of the females of the two species. At least in Sweden, females of L. sinapis appear to reach 
their flight optimum at lower temperatures than $L$. reali (Friberg et al., 2008c).

In central and north-western Europe L. sinapis generally prefers xerothermic habitats, whereas $L$. reali seems to be a generalist as regards habitat humidity (Beneš et al., 2003; Hughes \& Nelson, 2004; Verovnik \& Glogovčan, 2007; this work). In Ireland both of these apparent features of the L. sinapis habitat determine its distribution as it is confined to small areas covered by calcareous grassland and open hazel scrub, in contrast to the widespread distribution of L. reali (Hughes \& Nelson, 2004).

Data from Poland confirm that the population trends of the two species in Europe are different and opposite, suggesting different responses to environmental changes and anthropogenic effects. Despite overlapping ecological niches, there is no indication of inter-specific competition. In Poland the main host plants of the two species $L$. pratensis and L. corniculatus are eurytopic, widespread (Zajacc \& Zając, 2001) and there are no clear-cut ecological differences between them as regards light, thermal, moisture and soil fertility indicators (Zarzycki et al., 2002). Most likely, the expansion in range of $L$. reali and contraction of L. sinapis in Poland occurred independently, as indicated by the fact, that the western part of the country, the first part of the country from which $L$. sinapis disappeared, was the last to be colonised by $L$. reali.

The hypothesis postulating increase of $L$. reali populations and subsequent saturation of invaded areas may be supported by data from the urban area of Kraków city (S Poland), where the abundance of L. sinapis s. 1. was higher in the period 1973-2003 than in 1901-1972 (Palik et al., 2005). This trend ought to refer to L. reali, since only this species has been recorded in the Kraków city area (this work). Similar trends are recorded for a set of species, including Lycaena dispar and Cupido argiades, associated with open and semi-open habitats, apparently benefiting from plant succession and habitat eutrophication (Palik et al., 2005). It seems that L. reali is well adapted to the human altered habitats that dominate in central Europe (Beneš et al., 2003; this work).

The decline of L. sinapis in some parts of Europe may be related to changes in its habitat due to both natural and anthropogenic factors. Changes in forest management practices, causing fragmentation and overgrowth of the microhabitats (grassy glades and roadsides within larger woodland areas) of this butterfly, are recognized as the main reason for its decline in England (Warren, 1984). Its colonies are often confined to small areas and the exchange of individuals among them is very limited due to the sedentary lifestyle of the butterflies, and their poor ability to disperse and colonise new sites (Warren et al., 1986; Warren \& Bourn, 1998). In Poland L. sinapis is found mainly in clearings and along roadsides in coniferous and mixed forests as well as in xerothermic scrub and grassland at the edges of forests. Locally it coexists with rare and threatened butterflies with similar habitat requirements, such as Maculinea arion, Hipparchia alcy- one, Melitaea didyma and Glaucopsyche alexis (own data). Thus such marginal and unstable habitat patches have a high conservation value but are currently threatened by succession if abandoned for a long period or conversion to agriculture land.

ACKNOWLEDGEMENTS. We thank the following who made accessible specimens from museum collections: R. Dobosz (Museum of Upper Silesia in Bytom), W. Cichocki (The Tatras Museum in Zakopane), E. Kaczmarzyk (Regional Museum in Częstochowa), A. Malkiewicz (Zoological Museum, University of Wroclaw), B. Marciniak (Museum of Natural History, University of Łódź), D. Mierzwa (Museum and Institute of Zoology, Warsaw), K. Pałka (Museum of Natural History, University of Maria Curie-Skłodowska in Lublin), Ł. Przybyłowicz (Institute of Systematic and Evolution of Animals, Kraków). The following made accessible specimens from private collections: A. Baranowski, T. Blaik, D. Bruder, J. Bury, P. Danlowski, M. Gwardjan, P. Hirsz, T. Jaworski, K. Jonko, J. Kania, K. Kata, A. Kokot, M. Kutera, A. Larysz, S. Łuczkowski, D. Łupiński, M. Marciniak, J. Masłowski, W. Nowakowski, E. Palik, R. Rosa, D. Wasiluk. We are indebted to W. Żyła and T. Hadaś for their help in location of capture sites of some old specimens, to E. Kaczmarzyk, A. Malkiewicz and I. Ruczyński for providing some publications and to $\mathrm{T}$. Pawlikowski for granting access to photographic equipment and the LUCIA system. P. Senn and T. Dixon improved our English. We thank M. Friberg for valuable comments on the manuscript. The research project was supported in 2006-2008 by a grant from the State Committee for Scientific Research in Poland (N 30300131/0037).

\section{REFERENCES}

Aмiet J.L. 2004: Séparation des niches écologiques chez deux espèces jumelles sympatriques de Leptidea (Lepidoptera, Pieridae). Rev. Écol. (Terre et Vie) 59: 433-452.

Beneš J., KonvičKa M., VRabec V. \& ZÁmeČník J. 2003: Do the sibling species of small whites, Leptidea sinapis and L. reali (Lepidoptera, Pieridae) differ in habitat preferences? Biologia 58: 943-951.

BlaIK T. 2006: Butterflies (Lepidoptera: Hesperioidea, Papilionoidea) of anthropogenic habitats of Chełm. In Nowak A. \& Hebda G. (eds): Biodiversity of Quarries and Pits. Opole Górażdże, pp. 125-136.

Buszko J. 1997: The Distribution Atlas of Polish Butterflies 1986-1995. Turpress, Toruń, 170 pp.

Buszko J. \& Nowacki J. 2000: The Lepidoptera of Poland. A Distributional Checklist. PTE, Polish Entomological Monographs 1, Poznań - Toruń, 178 pp.

Cupedo F. \& Hoen F. W. 2006: Leptidea sinapis and Leptidea reali (Lepidoptera: Pieridae) in the Netherlands. Entomol. Berich. 66: 118-123.

EMBACHER G. 1996: Beitrag zur Verbreitung und Biologie von Leptidea sinapis (Linnaeus, 1758) and L. reali (Reissinger, 1989) (Lepidoptera: Pieridae, Dismorphiinae). Z. Arb. Gem. Öst. Entomol. 48: 107-112.

Freese A. \& Fiedler K. 2002: Experimental evidence for specific distinctness of the two wood white butterfly taxa, Leptidea sinapis and L. reali (Pieridae). Nota Lepid. 25: $39-59$.

Freese A. \& FiedLeR K. 2004: Unterscheidungsmerkmale von Leptidea sinapis (Linnaeus, 1758) und Leptidea reali Reissinger, 1989 (Lepidoptera, Pieridae) und ihre Eignung zur Artbestimmung. Nachr. Entomol. Ver. Apollo N. F. 25: 65-77. 
Friberg M. \& WiKLUND C. 2009: Host plant preference and performance of the sibling species of butterflies Leptidea sinapis and Leptidea reali: a test of the trade-off hypothesis for food specialisation. Oecologia 159: 127-137.

Friberg M., Bergman M., Kullberg J., Wahlberg N. \& WikLUND C. 2008a: Niche separation in space and time between two sympatric sister species - a case of ecological pleiotropy. Evol. Ecol. 22: 1-18.

Friberg M., Vongvanich N., Borg-Karlson A.K., Kemp D.J., Merilaita S. \& WikLund C. 2008b: Female mate choice determines reproductive isolation between sympatric butterflies. Behav. Ecol. Sociobiol. 62: 873-886.

Friberg M., Olofsson M., Berger D., Karlsson B. \& Wiklund C. 2008c: Habitat choice precedes host plant choice - niche separation in a species pair of a generalist and a specialist butterfly. Oikos 117: 1337-1344.

Gerstberger M. \& Woelky O. 2004: Die Tagfalterarten Leptidea sinapis (Linnaeus, 1758) und Leptidea reali Reissinger, 1989 in Berlin und Brandenburg. Märk. Entomol. Nachr. 6: 29-32.

Hughes M. \& Nelson B. 2004: Distribution of Leptidea reali and L. sinapis in Ireland. Unpubl. Report to the Cockayne Fund, $10 \mathrm{pp}$.

Karsholt O. 1999: Dagsommerfugleslægten Leptidea Billberg i Danmark. [The genus Leptidea in Denmark.]. Lepidoptera 7 : 237-249 [in Danish, English abstr.].

KudRna O. 2002: The Distribution Atlas of European Butterflies. Oedippus 20, Apollo Books, Stenstrup, 342 pp.

Lelo S. 2007: Contribution to knowledge of the fauna of butterflies in Bosnia and Herzegovina. Acta Entomol. Serbica 12: 73-92.

LoRKović Z. 1993: Leptidea reali Reissinger, 1989 (= lorkovicii Real, 1988), a new European species (Lepid., Pieridae). Nat. Croatica 2: 1-26.

Martin J.F., Gilles A. \& Descimon H. 2003: Species concepts and sibling species: the case of Leptidea sinapis and L. reali. In Boggs C.L., Watt W.B. \& Ehrlich P.R. (eds): Butterflies: Ecology and Evolution Taking Flight. University of Chicago Press, Chicago, pp. 459- 476.

Mazel R. \& EItschberger U. 2002: Répartition géographique de Leptidea sinapis (L., 1758) et L. reali Reissinger, 1989 au nord de l'Europe, en Russie et dans quelques pays d'Asie (Lepidoptera: Pieridae, Dismorphiinae). Linn. Belg. 18: 373-376.

Mazel R. \& Eitschberger U. 2003: Biogéographie de Leptidea reali Reissinger, 1989 en Europe at en Turquie. Rev. Ass. Roussill. Entomol. 12: 91-109.

Mazel R. \& Leestmans R. 1996: Relations biogéographiques, écologiques et taxonomiques entre Leptidea sinapis Linné et L. reali Reissinger en France, Belgique et régions limitrophes (Lepidoptera: Pieridae). Linn. Belg. 15: 317-331.

Mazel R. \& Leestmans R. 1999: Seconde contribution à l'étude des relations entre Leptidea sinapis Linné et L. reali Reissinger en France, Belgique et quelques autres contrées européennes (Lepidoptera: Pieridae). Linn. Belg. 17: 155-168.

Nelson B., Hughes M., Nash R. \& Warren M. 2001: Leptidea reali Reissinger, 1989 (Lep.: Pieridae): a butterfly new to Britain and Ireland. Entomol. Rec. 113: 97-102.

Palik E., PrzybyŁowicz Ł., Kosior A., Król W., Solarz W. \& Witkowski Z. 2005: Changes in the species composition and distribution of butterflies (Rhopalocera) in Cracow (Poland) since the mid-19th century. Fragm. Faun. 48: 181-215.

ReZBANYAI-Reser L. 2005: Allerlei Wissenswertes über die Zwillingsarten Leptidea sinapis (Linnaeus, 1758) und L. reali Reissinger, 1989 (= lorkovicii Réal, 1988) in der Schweiz und weitere Fundangaben aus einigen anderen Ländern Europas (Lepidoptera: Pieridae). Entomol. Ber. (Luzern) 54: 69-134.

SEgERER A.H. 2001: Beitrag zur Genitaldiagnose einiger bayerischer Tagfalterarten unter besonderer Berücksichtigung der Weibchen. Beitr. Bayer. Entomofaun. 4: 5-25.

Schmitz O. 2007: Neueste Kenntnisse zur historischen und aktuellen Verbreitung von Leptidea sinapis (Linnaeus, 1758) und Leptidea reali Reissinger, 1989 (Lepidoptera, Pieridae) im Arbeitsgebiet der AG rheinisch-westfälischer Lepidopterologen. Entomol. Heute 19: 181-195.

SkALSKI A.W. 1995: Genus Leptidea Billberg, 1820 in Poland (Lepidoptera: Pieridae). Acta Entomol. Siles. 3: 8-12 [in Polish, English abstr.].

VerovNiK R. \& GlogovČAn P. 2007: Morphological and molecular evidence of a possible hybrid zone of Leptidea sinapis and L. reali (Lepidoptera: Pieridae). Eur. J. Entomol. 104: 667-674.

Vila R., Viader S. \& Jubany J. 2003: Leptidea sinapis (Linnaeus, 1758) i L. reali Reissinger, 1989: dues espècies "bessones" a Catalunya i Andorra (Lepidoptera: Pieridae). Buttl. Soc. Cat. Lepid. 90: 25-47.

WARREN M.S. 1984: The biology and status of the wood white butterfly, Leptidea sinapis (L.) (Lepidoptera: Pieridae), in the British Isles. Entomol. Gaz. 35: 207-223.

WARREN M.S. 1985: The influence of shade on butterfly numbers in woodland rides, with special reference to the wood white Leptidea sinapis. Biol. Conserv. 33: 147-164.

WARREN M.S. \& BourN N.A.D. 1998: Species action plan: wood white Leptidea sinapis. Butterfly Conservation. Wareham, 24 pp., available at: www.butterfly-conservation.org.

Warren M.S., Pollard E. \& BibBy T.J. 1986: Annual and longterm changes in a population of the wood white butterfly Leptidea sinapis. J. Anim. Ecol. 55: 707-719.

ZAJAC A. \& ZAJAC M. (eds) 2001: Atlas of Vascular Plants Distribution in Poland. Institute of Botany, Jagiellonian University, Kraków, 786 pp. [in Polish, English abstr.].

Zarzycki K., TrZcińska-Tacik H., Różański W., Szelag Z., WoŁEK J. \& KorzenIAK U. 2002: Ecological Indicator Values of Vascular Plants of Poland. W. Szafer Institute of Botany, Polish Academy of Sciences, Kraków, 183 pp.

Received August 4, 2010; revised and accepted November 4, 2010 